\title{
A study of ethnobotany in Kumluca (Antalya)
}

\author{
Fatma Merve Nacakcı, ${ }^{a}$, İsmail Dutkuner ${ }^{a}$
}

\begin{abstract}
The Mediterranean region, which includes Kumluca, is a plant diversity hot spot. Traditionally, most of the plants in this region have many usage areas. This study was carried out from June 2014 to May 2015 to determine ethnobotanical characteristics of the plants in Kumluca (Antalya). Information on the usage areas of plants were obtained by face-to-face interviews with 255 people from this region. In the questionnaires, information such as age, gender, marital status, education level, occupation, social security, income level of respondents were recorded. In addition, the purpose and usage areas of plants (medicinal, food, spice, fodder, religious belief, etc.) were recorded with the usage instructions. While gathering information from survey participants, the fresh samples in the nature showed to the participants and asked explanation regarding to usage areas of the plants. The study revealed that 89 local taxa belonging to 51 families have ethnobotanical features. It was founded that commonly used families were Lamiaceae ( 9 taxa), Fabaceae (6 taxa), Rosaceae (6 taxa), Asteraceae (5 taxa) and Anacardiaceae (4 taxa). 132 different usage of these 89 taxa were determined and these were as follows; 37 (food), 38 (medicinal), 27 (tea), 13 (goods), 8 (fodder), 5 (ornament) and 4 (spice). Commonly used parts of these taxa were found as follows; above-ground part (39), fruit (18), flower (10), leaf (9) and cone (4). As such studies are_carried out_and the deficiencies in the literature are completed, plants that have been useful for humanity can be identified and transferred to future generations.

Keywords: Ethnobotany, Flora, Medicinal and aromatic plants, Kumluca
\end{abstract}

\section{Kumluca (Antalya)'da etnobotanik bir çalışma}

\begin{abstract}
Özet: Kumluca'yı da içine alan Akdeniz bölgesi, bitki çeşitliliği bakımından zengin bir bölgedir. Geleneksel olarak, bu bölgedeki bitkilerin çoğu, birçok kullanım alanına sahiptir. Bu çalışma Kumluca (Antalya) 'daki bitkilerin etnobotanik özelliklerini belirlemek için Haziran 2014'ten Mayıs 2015'e kadar gerçekleştirilmiştir. Bu bölgeden 255 kişi ile yüz yüze görüşmeler yapılarak bitkilerin kullanım alanları hakkında bilgi edinilmiştir. Anketlerde yaş, cinsiyet, medeni durum, eğitim durumu, meslek, sosyal güvenlik, ankete katılanların gelir düzeyleri gibi bilgiler kaydedilmiştir. Ayrıca bitkilerin (tıbbi, gıda, baharat, yem, dini inanç vb.) kullanım alanları kullanım talimatları ile birlikte kaydedilmiştir. Araştırmada katılımcılarından bilgi toplarken, doğadaki canlı örnekler katılımcılara gösterilmiş ve bitkilerin kullanım alanlarına ilişkin açıklama istenmiştir. Araştırma, 51 aileye ait 89 yerel taksonun etnobotanik özelliklere sahip olduğunu ortaya koymuştur. Yaygın olarak kullanılan ailelerin Lamiaceae $(9$ takson), Fabaceae (6 takson), Rosaceae (6 takson), Asteraceae (5 takson) ve Anacardiaceae (4 takson) olduğu saptanmıştır. Bu 89 taksonun 132 farklı kullanımı belirlenmiş ve bunlar aşağıdaki gibidir; 37 (gıda), 38 (tıbbi), 27 (çay), 13 (eşya), 8 (yem), 5 (süs) ve 4 (baharat). Bu taksonların yaygın olarak kullanılan kısımları şöyle bulunmuştur; toprak üstü kısım (39), meyve (18), çiçek (10), yaprak (9) ve kozalak (4). Bu tür çalışmalar yapıldığında ve literatürdeki eksiklikler tamamlandığında, insanlık için yararlı olan bitkiler tanımlanabilir ve gelecek nesillere aktarılabilir.
\end{abstract}

Anahtar kelimeler: Etnobotanik, Flora, Tibbi ve aromatik bitkiler, Kumluca

\section{Introduction}

According to Davis's "Flora of Turkey and the East Aegean Islands", there are 1251 genera and 10.000 species and subspecies (subspecies and varieties) of 174 families in Turkey. Considering that there are about 12.000 plant taxa in all of Europe, Turkey is very rich in vegetation (Kendir and Güvenç, 2010).

The local names used for these plants in Turkey can be differentiated over time. The name of any plant known to previous generations is now being used by the new generations with another name. This can be a big problem in the scientific studies about plants. When a locality is visited, it becomes difficult for scientists to communicate with people who know a plant with a different name, a name they have given themselves, and the integration of scientific studies with the public is prevented. In a study carried out, it is said that "local plant names should also be identified and updated in order for scientific data to integrate with the public" (Kendir and Güvenç, 2010). This update process can only be done with the help of ethnobotanical science.

Until today, various definitions have been made for ethnobotany. For example in 1932, Gilmore define ethnobotany as a sum of the economic botanism of a clan, the traditional knowledge diversity of all plant life and plants. In 1990, Wickens described ethnobotany as a study of useful plants before commercialization and possible tame, and in 1995 Martin described ethnobotany as all work related to plants that describe the interaction of native people with the natural environment.

\footnotetext{
$\triangle$ a Isparta Uygulamalı Bilimler Üniversitesi, Orman Fakültesi, Orman Mühendisliği Bölümü, Isparta

@ * Corresponding author (İletişim yazarı): mervenacakci@ sdu.edu.tr

$\checkmark \quad$ Received (Geliş tarihi): 08.05.2018, Accepted (Kabul tarihi): 12.07.2018
}

Citation (Atıf): Nacakc1, F.M, Dutkuner, İ., 2018. A study of ethnobotany in Kumluca (Antalya). Turkish Journal of Forestry, 19(2): 113-119. DOI: $\underline{10.18182 / \text { tjf.421970 }}$ 
During ethnobotanical studies there is need to use have related knowledge and some specific equipment. This information and equipment is listed in the "A manual of ethnobotany" as a criterion for being a good ethnobotanist. It is important that an ethnobotanist should have a sincere desire to understand the relationship between plants and humans (Jain, 2010). Having a sincere desire for human well-being and sustainable use of natural resources, obtaining knowledge about the flora of the region, understanding the drugs and their effects on body and having knowledge about common human diseases are the most desirable characteristics of a ethnobotanist (Jain, 2010). In addition to these, it is very important to diagnose plants accurately, to do an ethnobotanical study.

When doing an ethnobotanical study, firstly literature review should be done and previous ethnobotanical studies examined. After that a detailed work plan should be established. Then information about the flora of the region should be gathered. The answers of the questions such as which species are distributed, what is the average altitudes for species are answered through the flora studies about the region. If there is no previous flora study in that area, the researcher himself/herself should gain knowledge about flora by field surveys. Once primary knowledge about the flora has been gained, field trips should be conducted to collect some additional information from the local people who has enough experience about the usage areas of the local flora.

This study was carried out to determine ethnobotanical characteristics of the plants in Kumluca (Antalya) that were passed on to the present generation by the past generations, which have been known or forgotten by today's generation, and to transfer this information to future generations.

\section{Methodology}

\subsection{Study area}

Kumluca is a district of Antalya, located on the part of the Teke Peninsula in the western part of the Gulf of Antalya, in the Western Mediterranean region (Figure 1). Kumluca is located in $36^{\circ} 12^{\prime} 00^{\prime \prime}$ northern latitudes and $29^{\circ}$ $40^{\prime} 00^{\prime \prime}$ east longitudes and the district center is $3 \mathrm{~m}$ high from the sea. There is Mediterranean Sea in the south of the Kumluca, Finike in the west, Elmalı in the west and northwest direction.

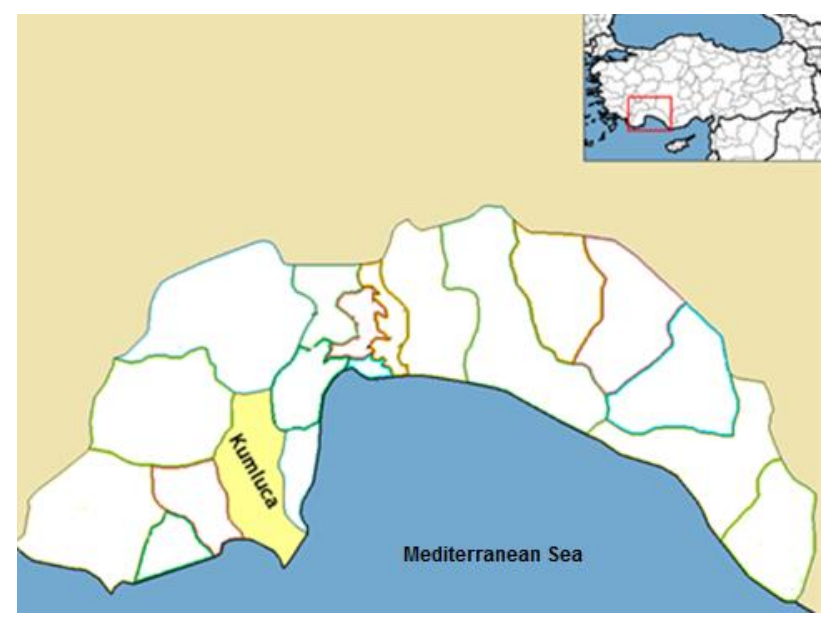

Figure 1. Location Map of Study Area
Since the area of study is located within the Mediterranean climate zone, the winters are warm and rainy and the summers are hot and dry. Precipitation is almost never seen in summer. The month with the highest average precipitation is January $(81.5 \mathrm{~mm})$, while the lowest rainfall comes in July $(0.0 \mathrm{~mm})$. The temperature difference between night and daytime is small. According to the meteorological data, the highest average temperature is seen in August $\left(34{ }^{\circ} \mathrm{C}\right)$, while the lowest average temperature is observed in February $\left(-2{ }^{\circ} \mathrm{C}\right)$. The average temperature in the vegetation period was $21.9^{\circ} \mathrm{C}$ (MGM, 2015).

The most common forest tree species in the area where the research is located is the Turkish Red Pine (Pinus brutia Ten.). Taurus Cedar (Cedrus libani A. Rich), Quercus, Juniperus and Cupressus species are the other common tree species in the field. Maquis vegetation of the region contained Ceratonia siliqua, Arbutus andrachne, Myrtus communis, Cornus mas, Pistacia terebinthus, Crataegus sp., Cistus sp., Phillyrea latifolia, Rhus coriaria, Cotinus coggygria, Laurus nobilis and Nerium oleander.

\subsection{Material}

The material of this study is constituted by plant samples that were collected and dried according to herbarium techniques from 27 villages belonging to Kumluca district, which were periodically visited between 2014 and 2015 .

\subsection{Method}

Plant samples were collected between 2014 and 2015, taking into account the flowering time of the plants and the time of fruit formation. Information on the use area of plants was obtained by face-to-face interviews with the 255 people in the places visited and recorded with the questionnaires. In the questionnaires, information such as age, gender, marital status, education level, occupation, social security, income level of respondents were recorded. In addition, the purpose and use area of plants (medicines, food, species, fodder, religious belief, etc.) were recorded with the usage instructions. While gathering information from survey participants, the fresh samples in the nature showed to the participants and asked explanation regarding to use area of the plants. After identification of plants and their usage patterns, the used parts of the plants were pressed and dried. Care has been taken to provide generative and vegetative organs such as fruits, flowers, leaves (grass leaves in grassy plants), buds, tubers, rhizomes and bulbs in order to ensure that the diagnostics of the collected plant samples can be carried out precisely and accurately. Information such as where the dried plant specimens were collected, gathering time, altitude and growth site characteristics were recorded and processed for the herbarium label generated for each plant (Saraç et. al, 2013). The diagnostics of plant samples were made according to "Flora of Turkey and the Aegean Islands" (Davis, 1965-88) and "Turkey Plant List" (Güner et al., 2012).

After obtaining the necessary preliminary information about the study area and the local people, interviews and written questionnaires should be applied to determine the usage area of the plants. The information gathered through these surveys and guides who know the area well would be helpful while collecting and categorizing the plants. If there is previous flora studies, the findings in these studies should 
be checked with local people. In this respect, it is ensured that all the species that are used in the region can be recorded. Interviews with local people and fieldwork can be conducted simultaneously. Surveys conducted to find out the patterns of use of the plants were conducted in Kumluca with 93 females and 152 males who are living in the region. Individuals were mostly 41 years-old and older, and their educational status was mostly secondary school. Since Kumluca is an agricultural province, the vast majority of individuals participating in the survey were farmers.

\section{Results}

The results showed that 89 taxa belonging to 51 families are naturally distributed in the Kumluca region and they are mostly classified as non-wood herbaceous forest products (Table 1). The result also showed that the local people used these plants for 132 different purposes.

Table 1. Ethnobotanical Species of the Kumluca Region

\begin{tabular}{|c|c|c|c|c|c|c|}
\hline No & Family & Scientific name & Local name & Used parts & Local uses & Usage \\
\hline 1 & Amaryllidaceae & Allium rotundum $\mathrm{L}$. & Körmen & Above-ground part & Food & It is consumed as uncooked. \\
\hline 2 & $\begin{array}{l}\text { Anacardiaceae } \\
\text { (Terebinthaceae) }\end{array}$ & $\begin{array}{l}\text { Pistacia terebinthus } \mathrm{L} . \\
\text { subsp. palaestina } \\
\text { (Boiss.) Engler }\end{array}$ & Menengiç & Fruit, Resin & Food & $\begin{array}{l}\text { Coffee is made from fruit; chewing } \\
\text { gum is made from its resin. }\end{array}$ \\
\hline 3 & $\begin{array}{l}\text { Anacardiaceae } \\
\text { (Terebinthaceae) }\end{array}$ & Pistacia lentiscus L. & Dat çalısı & Gum on truck & Food & $\begin{array}{l}\text { It is used in deserts and it is used as } \\
\text { chewing gum. }\end{array}$ \\
\hline 4 & $\begin{array}{l}\text { Anacardiaceae } \\
\text { (Terebinthaceae) }\end{array}$ & Rhus coriaria $\mathrm{L}$. & Sumak & Fruit & Spice & Its fruits are used as spice by pestling. \\
\hline 5 & $\begin{array}{l}\text { Anacardiaceae } \\
\text { (Terebinthaceae) }\end{array}$ & Cotinus coggygria Scop. & Boyac1 sumağ 1 & Above-ground part & Goods & It is used for making wreath. \\
\hline 6 & $\begin{array}{l}\text { Apiaceae } \\
\text { (Umbelliferae) }\end{array}$ & $\begin{array}{l}\text { Echinophora tenuifolia } \\
\text { subsp. sibthorpiana } \\
\text { (Guss.) Tutin }\end{array}$ & Çörtük otu & Leaf, flower & Spice & $\begin{array}{l}\text { Used as spice in pickles and fish } \\
\text { dishes. }\end{array}$ \\
\hline 7 & $\begin{array}{l}\text { Apiaceae } \\
\text { (Umbelliferae) }\end{array}$ & Eryngium sp. & Boğa dikeni & Above-ground part & Food & Leaves are consumed by cooking. \\
\hline 8 & Araliaceae & Hedera helix $\mathrm{L}$. & Sarmaşık & Above-ground part & Goods & $\begin{array}{l}\text { It is used as a canopy in the wooden } \\
\text { camellia. }\end{array}$ \\
\hline 9 & Aspleniaceae & Ceterach officinarum $\mathrm{L}$. & Altın otu & Above-ground part & $\begin{array}{l}\text { Medicinal, } \\
\text { Tea }\end{array}$ & $\begin{array}{l}\text { Leaves are drunk like tea in order to } \\
\text { pass kidney stones. }\end{array}$ \\
\hline 10 & $\begin{array}{l}\text { Asteraceae } \\
\text { (Compositae) }\end{array}$ & Achillea nobilus $\mathrm{L}$. & Ayvadana & Flower & $\begin{array}{l}\text { Tea, } \\
\text { Medicinal }\end{array}$ & $\begin{array}{l}\text { It is drunk like tea for cough and } \\
\text { stomach aches by brewing. }\end{array}$ \\
\hline 11 & $\begin{array}{l}\text { Asteraceae } \\
\text { (Compositae) }\end{array}$ & Calendula arvensis $\mathrm{L}$. & Aynısefa & Above-ground part & $\begin{array}{l}\text { Tea, } \\
\text { Ornament }\end{array}$ & $\begin{array}{l}\text { It is drunk like tea by brewing for liver } \\
\text { disorders. It is used as ornament plant. }\end{array}$ \\
\hline 12 & $\begin{array}{l}\text { Asteraceae } \\
\text { (Compositae) }\end{array}$ & Lactuca serriola $\mathrm{L}$. & Eşek marulu & $\begin{array}{l}\text { Root milk, Above- } \\
\text { ground part }\end{array}$ & Food & $\begin{array}{l}\text { Chewing gum is obtained from the } \\
\text { root milk. Above-ground parts are } \\
\text { consumed by cooking. }\end{array}$ \\
\hline 13 & $\begin{array}{l}\text { Asteraceae } \\
\text { (Compositae) }\end{array}$ & $\begin{array}{l}\text { Matricaria } \\
\text { chamomilla } \mathrm{L} .\end{array}$ & Papatya & Flower & $\begin{array}{l}\text { Tea, } \\
\text { Medicinal }\end{array}$ & $\begin{array}{l}\text { Its flowers are drunk like tea as an } \\
\text { anti-spasmodic by brewing. }\end{array}$ \\
\hline 14 & $\begin{array}{l}\text { Asteraceae } \\
\text { (Compositae) }\end{array}$ & Taraxacum wiggers spp. & Karahindiba & Leaf & Food & $\begin{array}{l}\text { Leaves are used in salads as a salad } \\
\text { plant. }\end{array}$ \\
\hline 15 & Berberidaceae & Berberis crataegina DC. & Karamuk & Fruit & Food & $\begin{array}{l}\text { Eat the fruits are eaten and marmalade } \\
\text { is made from the fruits. }\end{array}$ \\
\hline 16 & Boraginaceae & $\begin{array}{l}\text { Onosma tauricum Pallas } \\
\text { \&Willd }\end{array}$ & Emzik otu & Flower & Food & $\begin{array}{l}\text { The liquid in the flowers is absorbed } \\
\text { because of its nice taste. }\end{array}$ \\
\hline 17 & Cannabaceae & $\begin{array}{l}\text { Celtis glabrata Steven ex } \\
\text { Planchon }\end{array}$ & Çıtlık & Fruit & Food & Its fruits are eaten for stomach aches. \\
\hline 18 & Capparaceae & $\begin{array}{l}\text { Capparis spinosa L. var. } \\
\text { spinosa }\end{array}$ & Kapari & Bud & Food & Pickles are made from its buds. \\
\hline 19 & Caryophyllaceae & $\begin{array}{l}\text { Dianthus tripunctatus } \\
\text { Sibth. \& Sm. }\end{array}$ & Siğil otu & Above-ground part & $\begin{array}{l}\text { Tea, } \\
\text { Medicinal }\end{array}$ & $\begin{array}{l}\text { Its above-ground parts' water is drunk } \\
\text { by boiling and diluting for warts. }\end{array}$ \\
\hline 20 & Chenopodiaceae & $\begin{array}{l}\text { Chenopodium albüm } \mathrm{L} \text {. } \\
\text { subsp. albüm } \mathrm{L} \text {. }\end{array}$ & Sirken & Above-ground part & Food & Its leaves are cooked and eaten. \\
\hline 21 & Chenopodiaceae & $\begin{array}{l}\text { Chenopodium albüm } \\
\text { subsp. iranicum Aellen }\end{array}$ & Sirken & Above-ground part & Food & Its leaves are cooked and eaten. \\
\hline 22 & Cistaceae & Cistus creticus L. & Laden, fatmagül & Leaf & Medicinal & $\begin{array}{l}\text { Its leaves are drunk like tea for cancer } \\
\text { treatment by brewing. }\end{array}$ \\
\hline 23 & Cistaceae & Cistus laurifolius L. & Laden, fatmagül & Leaf & Medicinal & $\begin{array}{l}\text { Its leaves are drunk like tea for cancer } \\
\text { treatment by brewing. }\end{array}$ \\
\hline 24 & Cornaceae & Cornus mas $\mathrm{L}$. & Kizılc1k & Fruit & Food & $\begin{array}{l}\text { Edible, Syrup is made by mixing with } \\
\text { sugar and water. }\end{array}$ \\
\hline 25 & $\begin{array}{l}\text { Cruciferae } \\
\text { (Brassicaceae) }\end{array}$ & $\begin{array}{l}\text { Capsella bursa-pastoris } \\
\text { L. }\end{array}$ & Çobançantası & Above-ground part & Medicinal & $\begin{array}{l}\text { Leaves are used in salads as a salad } \\
\text { plant. }\end{array}$ \\
\hline 26 & $\begin{array}{l}\text { Cruciferae } \\
\text { (Brassicaceae) }\end{array}$ & $\begin{array}{l}\text { Nasturtium officinale } \mathrm{R} \text {. } \\
\mathrm{Br} \text {. }\end{array}$ & Su teresi & Above-ground part & Food & $\begin{array}{l}\text { It is used as astringent by putting on } \\
\text { the wound. }\end{array}$ \\
\hline 27 & $\begin{array}{l}\text { Cruciferae } \\
\text { (Brassicaceae) }\end{array}$ & Sinapis arvensis $\mathrm{L}$. & Turp otu & Above-ground part & Food, Fodder & $\begin{array}{l}\text { It is consumed as food, food is made. } \\
\text { It is also used as Fodder. }\end{array}$ \\
\hline 28 & Cucurbitaceae & $\begin{array}{l}\text { Ecballium elaterium (L.) } \\
\text { A. Rich. }\end{array}$ & Şeytan keleği & Fruit milk & Medicinal & $\begin{array}{l}3-4 \text { drops of } 1 \text { glass of water is diluted } \\
\text { and pulled to the nose is used in } \\
\text { sinusitis treatment. }\end{array}$ \\
\hline
\end{tabular}




\begin{tabular}{|c|c|c|c|c|c|c|}
\hline No & Family & Scientific name & Local name & Used parts & Local uses & Usage \\
\hline 29 & Cupressaceae & $\begin{array}{l}\text { Cupressus sempervirens } \\
\text { var. horizantalis } \mathrm{M} \text {. }\end{array}$ & Selvi & Cone & Medicinal & $\begin{array}{l}\text { It is boiled and brewed like tea for } \\
\text { bronchitis. }\end{array}$ \\
\hline 30 & Cupressaceae & $\begin{array}{l}\text { Juniperus oxycedrus L. } \\
\text { subsp. oxycedrus L. }\end{array}$ & Katran ardicı & Cone & $\begin{array}{l}\text { Food, } \\
\text { Medicinal }\end{array}$ & It is eaten raw for colds. \\
\hline 31 & Equisetaceae & $\begin{array}{l}\text { Equisetum ramosissimum } \\
\text { Desf. }\end{array}$ & Kırk kilit & Above-ground part & $\begin{array}{l}\text { Goods, Food, } \\
\text { Medicinal }\end{array}$ & $\begin{array}{l}\text { For kidney and bladder disturbances, } \\
\text { it is drunk like tea by brewing. Its } \\
\text { mush is used as cataplasm. }\end{array}$ \\
\hline 32 & Ericaceae & Arbutus andrachne L. & Sandal ağacı & Fruit, Leaf & Food, Goods & $\begin{array}{l}\text { Its fruits are eaten and used for } \\
\text { making wreaths. }\end{array}$ \\
\hline 33 & Ericaceae & $\begin{array}{l}\text { Erica manipuliflora } \\
\text { Salisb. }\end{array}$ & Püren & Above-ground part & Goods & It is used in making broom. \\
\hline 34 & Euphorbiaceae & $\begin{array}{l}\text { Euphorbia kotschyana } \\
\text { Fenzl }\end{array}$ & Sütleğen & Milk & Medicinal & $\begin{array}{l}\text { It is useful for warts and calluses. It is } \\
\text { poisonous and should be used with } \\
\text { caution. }\end{array}$ \\
\hline 35 & $\begin{array}{l}\text { Fabaceae } \\
\text { (Leguminosae) }\end{array}$ & Astragalus sp. & Geven & $\begin{array}{l}\text { Above-ground part, } \\
\text { tragacanth }\end{array}$ & $\begin{array}{l}\text { Fodder, } \\
\text { Goods }\end{array}$ & $\begin{array}{l}\text { Fresh leafy sprouts are used as fodder } \\
\text { and its tragacanth is used in } \\
\text { production of glue. }\end{array}$ \\
\hline 36 & $\begin{array}{l}\text { Fabaceae } \\
\text { (Leguminosae) }\end{array}$ & Ceratonia siliqua $\mathrm{L}$. & $\begin{array}{l}\text { Keçiboynuzu, } \\
\text { harnup }\end{array}$ & Fruit & Food & $\begin{array}{l}\text { The matured fruits are eaten. Molasses } \\
\text { is made from its fruits. Its molasses is } \\
\text { used against anemia and cough. }\end{array}$ \\
\hline 37 & $\begin{array}{l}\text { Fabaceae } \\
\text { (Leguminosae) }\end{array}$ & $\begin{array}{l}\text { Colutea cilicica } \text { Boiss. \& } \\
\text { Bal. }\end{array}$ & Patlak & Above-ground part & Tea & $\begin{array}{l}\text { The flowering branches are drunk like } \\
\text { tea by boiling and brewing for } \\
\text { constipation. }\end{array}$ \\
\hline 38 & $\begin{array}{l}\text { Fabaceae } \\
\text { (Leguminosae) }\end{array}$ & Medicago sativa $\mathrm{L}$. & Yonca & Above-ground part & Fodder & It is used as fodder. \\
\hline 39 & $\begin{array}{l}\text { Fabaceae } \\
\text { (Leguminosae) }\end{array}$ & Spartium junceum L. & Söğsük & Flower & Goods & $\begin{array}{l}\text { The flowers are used as brooms and } \\
\text { making wreaths. }\end{array}$ \\
\hline 40 & $\begin{array}{l}\text { Fabaceae } \\
\text { (Leguminosae) }\end{array}$ & Vicia sativa $\mathrm{L}$. & Fiğ & Above-ground part & Fodder & It is used as fodder. \\
\hline 41 & Fagaceae & Quercus coccifera $\mathrm{L}$. & Pelit, kermes & Above-ground part & Fodder & Leaves and fruits are used as fodder. \\
\hline 42 & Fagaceae & $\begin{array}{l}\text { Quercus aucheri Jaub. Et } \\
\text { Spach }\end{array}$ & $\begin{array}{l}\text { Boz pirnal, } \\
\text { piynar, pelit }\end{array}$ & Acorn & Food, Fodder & $\begin{array}{l}\text { It is eaten like chestnut and used as a } \\
\text { fodder. }\end{array}$ \\
\hline 43 & Geraniaceae & $\begin{array}{l}\text { Erodium moschatum (L.) } \\
\text { L'Herit }\end{array}$ & İğnelik & Above-ground part & Food & It is consumed by making food. \\
\hline 44 & $\begin{array}{l}\text { Guttiferae } \\
\text { (Hypericaceae) } \\
\text { (Clusiaceae) }\end{array}$ & $\begin{array}{l}\text { Hypericum perforatum } \\
\mathrm{L} .\end{array}$ & Sar1 kantaron & Oil & $\begin{array}{l}\text { Goods, } \\
\text { Medicinal }\end{array}$ & $\begin{array}{l}\text { It is applied externally or drunk as } \\
\text { wound healing and astringent }\end{array}$ \\
\hline 45 & Iridaceae & Crocus biflorus Mill. & Çiğdem & Tuber & $\begin{array}{l}\text { Food, } \\
\text { Ornament }\end{array}$ & $\begin{array}{l}\text { It is consumed as food. It is used as } \\
\text { ornamental plant. }\end{array}$ \\
\hline 46 & Juglandaceae & Juglans regia $\mathrm{L}$. & Ceviz, koz & Fruit & Food & $\begin{array}{l}\text { It is eaten; it is put in dessert, pasta, } \\
\text { baklava-like foods. }\end{array}$ \\
\hline 47 & $\begin{array}{l}\text { Labiatae } \\
\text { (Lamiaceae) }\end{array}$ & $\begin{array}{l}\text { Lavandula stoechas } \mathrm{L} . \\
\text { subsp. stoechas Bonnier. }\end{array}$ & Karabaş otu & Flower & $\begin{array}{l}\text { Tea, } \\
\text { Medicinal }\end{array}$ & $\begin{array}{l}\text { It is drunk like tea by brewing for } \\
\text { vessel stiffness and cancer of tumors. }\end{array}$ \\
\hline 48 & $\begin{array}{l}\text { Labiatae } \\
\text { (Lamiaceae) }\end{array}$ & Phlomis sp. & Çalba & Above-ground part & $\begin{array}{l}\text { Tea, } \\
\text { Medicinal }\end{array}$ & $\begin{array}{l}\text { It is drunk like tea by brewing for } \\
\text { colds. }\end{array}$ \\
\hline 49 & $\begin{array}{l}\text { Labiatae } \\
\text { (Lamiaceae) }\end{array}$ & $\begin{array}{l}\text { Sideritis libanotica } \\
\text { subsp. linearis (Benth.) } \\
\text { Bornm. }\end{array}$ & Toros çayı & Above-ground part & $\begin{array}{l}\text { Tea, } \\
\text { Medicinal }\end{array}$ & $\begin{array}{l}\text { It is drunk like tea by brewing for } \\
\text { colds. }\end{array}$ \\
\hline 50 & $\begin{array}{l}\text { Labiatae } \\
\text { (Lamiaceae) }\end{array}$ & $\begin{array}{l}\text { Sideritis condensata } \\
\text { Boiss. \& Heldr. }\end{array}$ & Kozalı kekik & Above-ground part & $\begin{array}{l}\text { Tea, } \\
\text { Medicinal }\end{array}$ & $\begin{array}{l}\text { It is drunk like tea for sniffles and } \\
\text { asthma by brewing. }\end{array}$ \\
\hline 51 & $\begin{array}{l}\text { Labiatae } \\
\text { (Lamiaceae) }\end{array}$ & Origanum onites L. & Bilyalı kekik & Above-ground part & $\begin{array}{l}\text { Tea, } \\
\text { Medicinal }\end{array}$ & $\begin{array}{l}\text { It is drunk like tea by brewing for } \\
\text { colds. }\end{array}$ \\
\hline 52 & $\begin{array}{l}\text { Labiatae } \\
\text { (Lamiaceae) }\end{array}$ & Satureja thymbra L. & Çorba kekiği & Above-ground part & Spice & $\begin{array}{l}\text { Freshly flowered stems are dried and } \\
\text { added to soups and foods as spice. For } \\
\text { the flu and cough, it is drunk as tea by } \\
\text { brewing. }\end{array}$ \\
\hline 53 & $\begin{array}{l}\text { Labiatae } \\
\text { (Lamiaceae) }\end{array}$ & Mentha pulegium $\mathrm{L}$. & Yarpuz & Above-ground part & $\begin{array}{l}\text { Tea, } \\
\text { Medicinal }\end{array}$ & $\begin{array}{l}\text { For asthma, it is drunk like tea by } \\
\text { brewing. }\end{array}$ \\
\hline 54 & $\begin{array}{l}\text { Labiatae } \\
\text { (Lamiaceae) }\end{array}$ & $\begin{array}{l}\text { Teucrium chamaedrys } \\
\text { Boiss. }\end{array}$ & Bodur Mahmut & Above-ground part & $\begin{array}{l}\text { Tea, } \\
\text { Medicinal }\end{array}$ & $\begin{array}{l}\text { It is drunk like tea as antifebrile by } \\
\text { brewing. }\end{array}$ \\
\hline 55 & $\begin{array}{l}\text { Labiatae } \\
\text { (Lamiaceae) }\end{array}$ & Teucrium polium $\mathrm{L}$. & Bodur Mahmut & Above-ground part & $\begin{array}{l}\text { Medicinal, } \\
\text { Tea }\end{array}$ & $\begin{array}{l}\text { It is drunk like tea as antifebrile by } \\
\text { brewing. }\end{array}$ \\
\hline 56 & Lauraceae & Laurus nobilis L. & Defne & Leaf, Oil & $\begin{array}{l}\text { Spice, Tea, } \\
\text { Medicinal }\end{array}$ & $\begin{array}{l}\text { Leaves are used as spice and tea. Oil } \\
\text { of matured seeds is used for soften the } \\
\text { chest, and cold. And it is also used as } \\
\text { antitussive }\end{array}$ \\
\hline 57 & Liliaceae & Asparagus acutifolius L. & Tilkicen & Sprout & Food & It is eaten cooked with egg. \\
\hline 58 & Loranthaceae & $\begin{array}{l}\text { Viscum albumsubsp. } \\
\text { album } \mathrm{L} .\end{array}$ & Ökse otu, burç & Above-ground part & $\begin{array}{l}\text { Tea, } \\
\text { Medicinal, } \\
\text { Fodder }\end{array}$ & $\begin{array}{l}\text { It is drunk with decoction method for } \\
\text { diabetes by dried. It is used as fodder. } \\
\text { Its fruits are poisonous. }\end{array}$ \\
\hline 59 & Malvaceae & Alcea heldreichii Boiss. & Hatmi & Flower & Medicinal & $\begin{array}{l}\text { It is brewed like tea and drunk for dry } \\
\text { cough. }\end{array}$ \\
\hline 60 & Malvaceae & Malva sylvestris $\mathrm{L}$. & Ebegümeci & Above-ground part & Food & $\begin{array}{l}\text { It is eaten by cooking. Its mash is } \\
\text { wrapped to painful places. }\end{array}$ \\
\hline
\end{tabular}


Turkish Journal of Forestry 2018, 19(2): 113-119

\begin{tabular}{|c|c|c|c|c|c|c|}
\hline No & Family & Scientific name & Local name & Used parts & Local uses & Usage \\
\hline 61 & Myrtaceae & Myrtus communis L. & Mersin & Fruit, Leaf & $\begin{array}{l}\text { Food, } \\
\text { Medicinal }\end{array}$ & $\begin{array}{l}\text { Fruits are eaten. Leaves are drunk like } \\
\text { tea by brewing to lower cholesterol. }\end{array}$ \\
\hline 62 & Oleaceae & $\begin{array}{l}\text { Olea europaea var. } \\
\text { sylvestris (Miller.) Lehr }\end{array}$ & Delice & Fruit, Oil & $\begin{array}{l}\text { Food, Tea, } \\
\text { Medicinal }\end{array}$ & $\begin{array}{l}\text { Fruits are eaten. Leaves are drunk like } \\
\text { tea by brewing. Olive oil is obtained } \\
\text { from fruits. }\end{array}$ \\
\hline 63 & Oleaceae & Phillyrea latifolia $\mathrm{L}$. & Akçakesme & Above-ground part & $\begin{array}{l}\text { Fodder, } \\
\text { Goods }\end{array}$ & $\begin{array}{l}\text { It is used as fodder. It is also used as } \\
\text { bush broom. }\end{array}$ \\
\hline 64 & Orchidaceae & $\begin{array}{l}\text { Barlia robertiana } \\
\text { (Loisel.) Greuter }\end{array}$ & Salep & Tuber & Tea & It is drunk with milk or plain. \\
\hline 65 & Orchidaceae & $\begin{array}{l}\text { Ophrys lutea subsp. } \\
\text { minor (Guss.) O. \& E. } \\
\text { Danesch }\end{array}$ & Salep & Tuber & Tea & It is drunk with milk or plain. \\
\hline 66 & Orchidaceae & $\begin{array}{l}\text { Orchis spitzelii Sauterex } \\
\text { W. Koch }\end{array}$ & Dağ salebi & Tuber & Tea & It is drunk with milk or plain. \\
\hline 67 & Papaveraceae & Papaver rhoeas $\mathrm{L}$. & Gelincik & Above-ground part & Food & $\begin{array}{l}\text { Before the flowering stem is } \\
\text { consumed by making the food. }\end{array}$ \\
\hline 68 & Pinaceae & Pinus brutia Ten. & Kızılçam & Cone, Resin, Floem & $\begin{array}{l}\text { Tea, } \\
\text { Medicinal, } \\
\text { Food }\end{array}$ & $\begin{array}{l}\text { Green cones are boiled and drunk for } \\
\text { asthma and bronchitis. } 1 \text { year button- } \\
\text { shaped resins are used as gum. The } \\
\text { floems are eaten. }\end{array}$ \\
\hline 69 & Pinaceae & $\begin{array}{l}\text { Cedrus libani A. Rich. } \\
\text { var. libani }\end{array}$ & Katran & Cone & $\begin{array}{l}\text { Medicinal, } \\
\text { Tea, Goods }\end{array}$ & $\begin{array}{l}\text { Its cones are boiled and drunk for } \\
\text { hemorrhoids. Put it in the flour sack as } \\
\text { a preventive and to prevent insects. }\end{array}$ \\
\hline 70 & Plantaginaceae & Plantago lanceolata $\mathrm{L}$. & Sinirli ot & Leaf & Medicinal & $\begin{array}{l}\text { Fresh leaf is crushed and applied on } \\
\text { wounds. It is poisonous. }\end{array}$ \\
\hline 71 & Platanaceae & Platanus orientalis L. & Çınar, kavak & Leaf & $\begin{array}{l}\text { Tea, } \\
\text { Medicinal }\end{array}$ & $\begin{array}{l}\text { For knee arthritis and rheumatism, it is } \\
\text { dried and drunk like tea by brewing }\end{array}$ \\
\hline 72 & $\begin{array}{l}\text { Poaceae } \\
\text { (Gramineae) }\end{array}$ & $\begin{array}{l}\text { Elymus repens (L.) } \\
\text { Gould subsp. repens (L.) } \\
\text { Gould }\end{array}$ & Ayrik otu & Root & $\begin{array}{l}\text { Medicinal, } \\
\text { Tea }\end{array}$ & $\begin{array}{l}\text { Roots are boiled and drunk for } \\
\text { diabetes. }\end{array}$ \\
\hline 73 & Polygonaceae & Rumex crispus L. & Labada, ilibada & Above-ground part & Food & $\begin{array}{l}\text { Leaves are consumed as food by } \\
\text { wrapping. }\end{array}$ \\
\hline 74 & Portulacaceae & Portulaca oleracea $\mathrm{L}$. & Semizotu & Above-ground part & Food & $\begin{array}{l}\text { Above-ground parts are put in a salad. } \\
\text { Food is made. It is consumed because } \\
\text { of it is rich in omega } 3 \text {. }\end{array}$ \\
\hline 75 & Primulaceae & $\begin{array}{l}\text { Cyclamen coum var. } \\
\text { coum } \text { Miller }\end{array}$ & Siklamen & Flower & Ornament & It is used as ornamental plant. \\
\hline 76 & Ranunculaceae & Anemone coronaria $\mathrm{L}$. & Anemon, lale & Above-ground part & Ornament & $\begin{array}{l}\text { It is used as ornamental plant in the } \\
\text { gardens of houses. }\end{array}$ \\
\hline 77 & Rhamnaceae & $\begin{array}{l}\text { Paliurus spina-christii } \\
\text { Miller }\end{array}$ & Karaçalı & Fruit & $\begin{array}{l}\text { Tea, } \\
\text { Medicinal }\end{array}$ & $\begin{array}{l}\text { It is boiled and drunk for stone } \\
\text { reduction and diabetes. }\end{array}$ \\
\hline 78 & Rosaceae & $\begin{array}{l}\text { Amygdalus orientalis } \\
\text { Miller. }\end{array}$ & Ac1 payam & Fruit & Medicinal & Fresh fruit is eaten for diabetes. \\
\hline 79 & Rosaceae & $\begin{array}{l}\text { Crataegus monogyna } \\
\text { subsp. monogyna Jacq. }\end{array}$ & Alıç & Fruit & Food & $\begin{array}{l}\text { Fruits are eaten. Flowers are drunk by } \\
\text { brewing and barks are drunk for } \\
\text { cholesterol by boiling. }\end{array}$ \\
\hline 80 & Rosaceae & $\begin{array}{l}\text { Pyrus elaeagnifolia } \\
\text { subsp. elaeagnifolia } \\
\text { Pallas }\end{array}$ & Ahlat & Fruit, Flower & $\begin{array}{l}\text { Food, } \\
\text { Medicinal }\end{array}$ & $\begin{array}{l}\text { Fruits are eaten. Dried flowers are } \\
\text { brewed like tea, drunk for heart } \\
\text { problems and bronchitis. }\end{array}$ \\
\hline 81 & Rosaceae & Rosa canina $\mathrm{L}$. & $\begin{array}{l}\text { Kuşburnu, it } \\
\text { gülü }\end{array}$ & Fruit & $\begin{array}{l}\text { Tea, } \\
\text { Medicinal, } \\
\text { Food }\end{array}$ & $\begin{array}{l}\text { Its fruits are drunk like tea by brewing } \\
\text { against colds. Marmalade is also } \\
\text { made. }\end{array}$ \\
\hline 82 & Rosaceae & Rubus sanctus Schreber. & Böğürtlen & Fruit & Food & It is eaten and jam is made from fruits. \\
\hline 83 & Rosaceae & Prunus cocomilia Ten. & Çakal eriği & Fruit & Food & $\begin{array}{l}\text { It is eaten and compote is made from } \\
\text { dried fruits. }\end{array}$ \\
\hline 84 & Scrophulariaceae & Verbascum spp. & Siğırkuyruğu & Flower & Medicinal & $\begin{array}{l}\text { It is drunk like tea with decoction } \\
\text { method against coughing and sound } \\
\text { discomfort. It is poisonous. }\end{array}$ \\
\hline 85 & Styracaceae & Styrax officinalis L. & Tespih çalısı & Fruit, Balsam & Goods & $\begin{array}{l}\text { Rosaries are made from fruits. The } \\
\text { balsam coming out of the body is used } \\
\text { a mystical smell for religious days. }\end{array}$ \\
\hline 86 & Thymelaeaceae & Daphne sericea Vahl. & Ezelbahar & Above-ground part & $\begin{array}{l}\text { Ornament, } \\
\text { Goods }\end{array}$ & $\begin{array}{l}\text { Flowering branches are used in broom } \\
\text { construction. It is also used } \\
\text { ornamental plant in the gardens. It is } \\
\text { poisonous. }\end{array}$ \\
\hline 87 & Urticaceae & Urtica dioica $\mathrm{L}$. & Isırgan & Above-ground part & $\begin{array}{l}\text { Food, } \\
\text { Medicinal }\end{array}$ & $\begin{array}{l}\text { It is cooked and eaten to protect } \\
\text { against cancer. It is also used in pie } \\
\text { making. }\end{array}$ \\
\hline 88 & Verbenaceae & Vitex agnus-castus L. & Hayit & Root ash & Goods & $\begin{array}{l}\text { It is used as detergent in laundry. Its } \\
\text { seeds are used as carminative as } \\
\text { cataplasm. }\end{array}$ \\
\hline 89 & Zygophyllaceae & Tribulus terrestris $\mathrm{L}$. & Demir bıtırağı & Above-ground part & $\begin{array}{l}\text { Tea, } \\
\text { Medicinal }\end{array}$ & $\begin{array}{l}\text { It is drunk like tea for heart diseases } \\
\text { by brewing. }\end{array}$ \\
\hline
\end{tabular}


Information about ethnobotanical use was lacking for 11 taxa (out of 89) and this study provided new contributions to the literature. These species are; Allium rotundum L. as food, Eryngium sp. as food, Lactuca serriola L. as food, Onosma tauricum Pallas \& Willd as medicine, Dianthus tripunctatus Sibth. \& Amp; Sm. as food, Nasturtium officinale $\mathrm{R}$. Br. as fodder, Quercus aucheri Jaub. Meat Spach as ornamental and food, Crocus biflorus Mill. as food and fodder, Phillyrea latifolia L. as ornamental and food, Anemone coronaria L. as fodder and goods, Styrax officinalis L. as ornamental and goods.
When the taxa detected in the region are examined, it is seen that the family of Labiatae (Lamiaceae) was the most used family by the local people, represented by 9 species (Figure 2). Other frequently used families are Fabaceae (6), Rosaceae (6), Asteraceae (5), Anacardiaceae (4), Orchidaceae (3) and Cruciferae (3). When the used parts of the taxa are examined, it is seen that above-ground parts are the most commonly used part of the plants, represented by 39 taxa (Figure 3). Other commonly used parts of the plants are: Fruit (18), flower (10), leaf (9) and cone (4). 89 taxa identified in the region have 132 use areas; 38 are medical, 37 are food, 27 are tea, 13 are ware, 8 are animal food, 5 are ornament, 4 are spice (Figure 4).

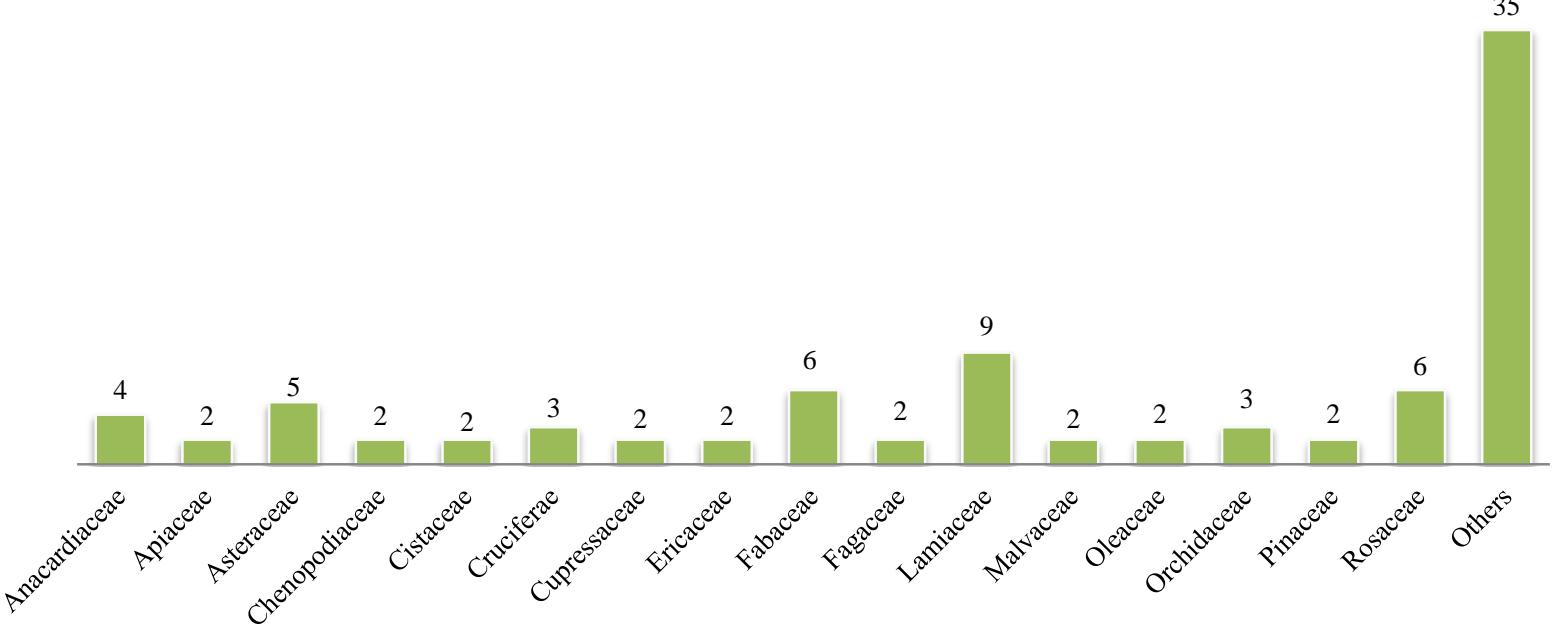

Figure 2. Number of species by families found in the region

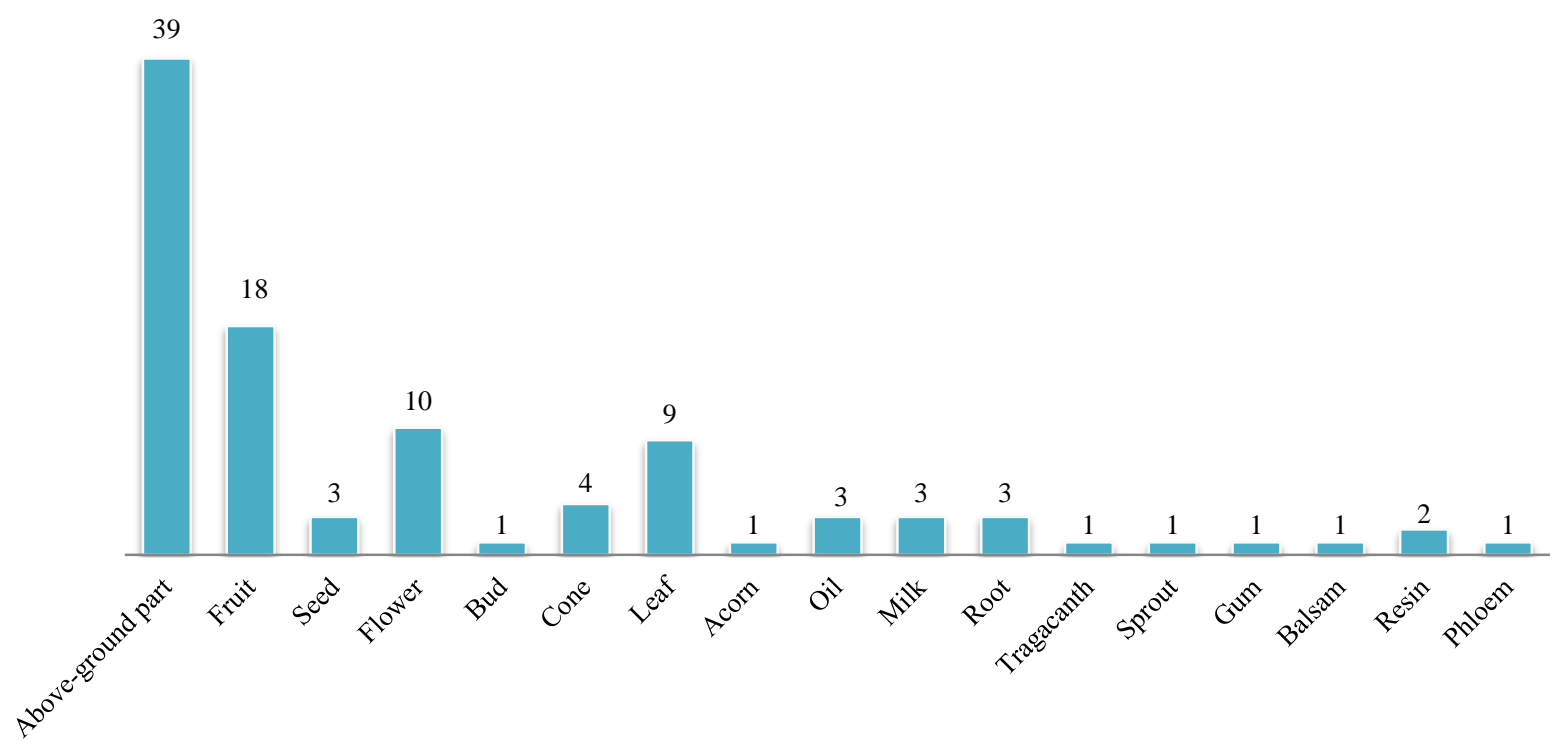

Figure 3. Number of species by different used parts 


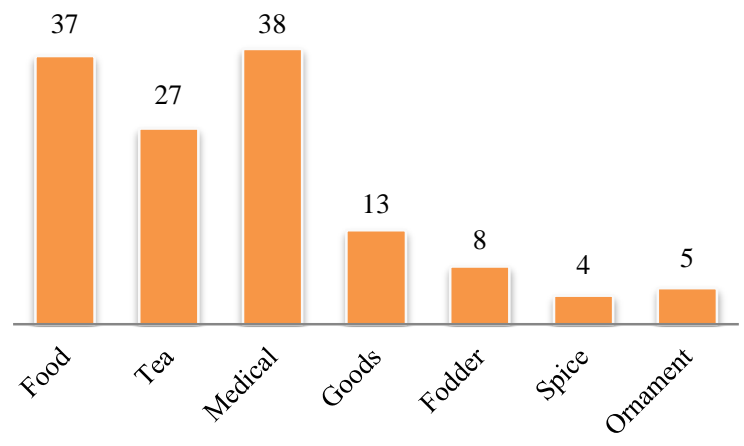

Figure 4. Number of usage purposes plants in the region

\section{Discussion and conclusion}

Arıcan et al. (2013) have identified 31 taxa belonging to 21 families in the preliminary work carried out in this region, and mainly the medical uses of these taxa are emphasized. In this study, 89 taxa belonging to 51 families were detected, but it is seen that these plants were not only used for medical purposes but also for other uses such as food, tea, species and ornaments. Because of these features, our work is more comprehensive than the work Arican et al. (2013) have done.

There are many ethnobotanical studies in the Western Mediterranean region so far. For example, Özçelik (1987), Erol (1995), Duran (1998), Düşen and Sümbül (1999), Doğanoğlu (2004), Özçelik and Balabanlı (2005), Bulut (2006), Büyükgebiz et al (2008), Fakir et al. (2009), Korkmaz and Fakir (2009), Arıcan et al. (2013), Başaran (2003), Arıtuluk (2010) and Şenkardeş and Tuzlacı (2014) made ethnobotanical studies in the Western Mediterranean region of Turkey and it seems that our study overlaps with this literature.

Such studies will ensure that information about the plants used by people is passed on to future generations. Also ethnobotanical studies help identifying plants' potential area of use which will open new business areas and create income sources for people. Moreover, the use of a plant for any medical purpose may be inspiring for the pharmaceutical industry. For these reasons, it is necessary for countries to regard all plant assets as a value and to keep track of ethnobotanical studies and information on all plants.

\section{Acknowledgement}

This article is a summary of a part of the Master's thesis prepared at Suleyman Demirel University Institute of Science and was supported by the SDU Scientific Research Projects and Coordination Unit as a research project of 4248-YL1-15.

\section{References}

Arıcan, Y.E., Yeşil, E., Ecevit Genç, G., 2013. A preliminary ethnobotanical survey of Kumluca (Antalya). Journal of Faculty of Pharmacy İstanbul, 43(2): 95-102.

Arıtuluk, Z. C., 2010. Flora and folk medicines of Tefenni (Burdur) district. MSc Thesis, Hacettepe University, Graduate School of Health Sciences, Ankara.
Başaran, S., 2003. Elmalı yöresinde doğal olarak yetişen bazı bitkilerin etnobotanik özellikleri. Batı Akdeniz Ormancılık Araştırma Müdürlüğ̈̈ Dergisi, Say1 5.

Bulut, Y., 2006. Useful plants of Manavgat District (Antalya). MSc Thesis, Suleyman Demirel University Graduate School of Natural and Applied Sciences, Isparta.

Büyükgebiz, T., Fakir, H., Negiz, M. G., 2008. Sütçüler (Isparta) Yöresinde Doğal Odun Dışı Bitkisel Orman Ürünleri ve Geleneksel Kullanımları. Süleyman Demirel Üniversitesi Orman Fakültesi Dergisi, 1: 109-120.

Davis, P. H., 1965-88. Flora of Turkey and the Aegean Islands I-X. Edinburg University Press, England.

Doğanoğlu, Ö., 2004. Yenişarbademli-Isparta Yöresindeki Doğal Faydalı Bitkiler Üzerine Araştırmalar. MSc Thesis, Suleyman Demirel University Graduate School of Natural and Applied Sciences, Isparta.

Duran, A., 1998. Akseki (Antalya) ilçesindeki bazı bitkilerin yerel adları ve etnobotanik özellikleri. Ot Sistematik Botanik Dergisi 5(1): 72-92.

Düşen, O., Sümbül, H., 1999. Antalya ve çevresinde yayılış gösteren bazı bitkilerin etnobotanik özellikleri. Tabiat ve İnsan, 4: 9-17.

Erol, M. K., 1995. Eğirdir (Isparta) Yöresinin Geleneksel Halk İlacı Olarak Kullanılan Bitkileri. MSc Thesis, Marmara University Graduate School of Health Sciences, İstanbul.

Fakir, H., Korkmaz, M., Güller, B., 2009. Medicinal Plant Diversity of Western Mediterrenean Region in Turkey. Journal of Applied Biological Sciences, 3(2): 30-40.

Gilmore, M. R., 1932. Importance of ethnobotanical investigations. American Anthropologist, 34 (2): 320-327.

Güner, A., Aslan, S., Ekim, T., Vural, M., Babaç, M.T. (Eds.), 2012. Türkiye Bitkileri Listesi/Damarlı Bitkiler. Nezahat Gökyiğit Botanik Bahçesi ve Flora Araştırmaları Derneği Yayını, Istanbul, Türkiye.

Jain, S. K., 2010. A Manual of Ethnobotany. Scientific Publishers, Jodhpur.

Kendir, G., Güvenç, A., 2010. Etnobotanik ve Türkiye'de Yapılmış Etnobotanik Çalışmalara Genel Bir Bakış. Journal of Hacettepe University Faculty of Pharmacy, 30 (1): 4980.

Korkmaz, M., Fakir, H., 2009. Odun Dışı Bitkisel Orman Ürünlerine İlişkin Nihai Tüketici Özelliklerinin Belirlenmesi. Journal of Suleyman Demirel University Faculty of Forestry, 2: 10-20.

Martin, G. J., 1995. Ethnobotany: A Concervation Manual. Chapman \& Hall, London.

MGM, 2015. General Directorate of Meteorology, Turkey https://www.mgm.gov.tr/?il=Antalya,Accessed: 09.01.2015

Özçelik, H., Balabanl1, C., 2005. Medicinal and Aromatic Plants of Burdur Province. I.Burdur Symposium Proceeding Book, 1127-1136.

Özçelik, H., 1987. The local names and uses of some useful plants naturally grown in the Akseki region. Journal of Nature Agriculture and Forest Botanic, 11(3): 316-321.

Saraç, D. U., Özkan, Z. C., Akbulut S, 2013. Ethnobotanic features of Rize/Turkey province. Biological Diversity of Conservation, 6(3): 57-66.

Senkardeş, I., Tuzlaci, E., 2014. Some Ethnobotanical Notes from Gundogmus District (Antalya/Turkey). Marmara Üniversitesi Saglik Bilimleri Enstitüsü Dergisi, 4(2): 63.

Wickens, G. E., 1990. What is economic botany?. Economic Botany, 44: 12-28. 